
\title{
Ailing:H: Beleidsonderzoekonline
}

Citeerwijze van dit artikel:

Esther van Asselt, Sjoukje Osinga, Mariska Asselman en Piet Sterrenburg, 'Agent Based Modeling: het simuleren van nalevingsgedrag', bso 2012, oktober-december, DOI: 10.5553/Beleidsonderzoek.000015

DOI: 10.5553/Beleidsonderzoek.000015

\section{Agent Based Modeling: het simuleren van nalevingsgedrag}

Esther van Asselt, Sjoukje Osinga, Mariska Asselman en Piet Sterrenburg

\section{Introductie}

Van levensmiddelenproducenten wordt verwacht dat ze veilig voedsel op de markt brengen. Dit betekent in de praktijk dat het voedsel moet voldoen aan de Europese wetgeving, zoals beschreven in onder andere EC/178/2002 en EC/852/2004. De mate waarin bedrijven de wet naleven, verschilt echter per bedrijf en kan bevorderd worden door middel van voorlichting en/of het opleggen van sancties (Van Asselt et al., 2012). Nalevingsgedrag wordt beïnvloed door verschillende factoren. Zo spelen economische aspecten een rol, die bijvoorbeeld beschreven zijn in de Expected Utility Theory. Dit is een economisch kader waarin de kosten en baten die individuen tegen elkaar afwegen in relatie tot naleving in kaart zijn gebracht (Herzfeld \& Jongeneel, 2012). Factoren die hierbij een rol spelen, zijn de kans op inspectie en detectie, de ernst van de sanctie en risicovermijdend gedrag van individuen. Naast economische belangen spelen ook individuele factoren een rol, die niet voor iedereen gelijk zijn, zoals persoonlijkheid, opleiding, beschikbare informatie, kennis en mogelijkheden. Ajzen en Fishbein (2010) hebben deze aspecten beschreven in de 'Reasoned Action Approach', een uitbreiding van hun eerdere 'Theory of Planned Behaviour'. De theorie gaat ervan uit dat iemands gedrag afhangt van zijn houding ten opzichte van het gedrag, in welke mate iemand beïnvloed wordt door zijn omgeving en de mate waarin hij controle kan uitoefenen op zijn gedrag.

Dergelijke theoretische kaders rondom economische, sociale, psychologische en institutionele factoren zijn door het ministerie van Justitie gebruikt voor de ontwikkeling van de zogenoemde 'Tafel van Elf' (T11) om de mate van naleving te kunnen inschatten en de sterke en zwakke punten in wetsnaleving in kaart te brengen (CCV 2010). De T11 bevat zowel dimensies van spontane naleving als handhavingsdimensies, zoals weergegeven in tabel 1.

\section{De dimensies van de Tafel van Elf (CCV 2010) \\ Nr Dimensie \\ Definitie \\ Spontane nalevingsdimensies}

1 Kennis van de De bekendheid met wet- en regelgeving bij de doelgroep en de duidelijkheid ervan.

2 Kosten/baten De (im)materiële voor- en nadelen die uit het overtreden of naleven van de regel(s) volgen, uitgedrukt in tijd, geld en moeite.

3 Mate van De mate waarin de doelgroep het beleid en de regelgeving van de overheid acceptabel vindt.

Gezagsgetrouwheid De mate waarin de doelgroep bereid is zich te conformeren aan het gezag van de overheid of aan eigen

4 doelgroep normen en waarden.

5 Sociale controle De door de doelgroep ingeschatte kans op positieve of negatieve sanctionering van hun gedrag door Handhavingsdimensies

6 Meldingskans De door de doelgroep ingeschatte kans dat een overtreding die is geconstateerd door anderen dan de overheid, wordt gemeld aan overheidsinstanties.

7 Controlekans De door de doelgroep ingeschatte kans dat men door de overheid gecontroleerd wordt op het begaan van een overtreding.

8 Detectiekans De door de doelgroep ingeschatte kans op constatering van de overtreding indien door de overheid gecontroleerd wordt.

9 Selectiviteit De (verhoogde) gepercipieerde kans op controle en detectie in het geval van een overtreding door selectie van te controleren bedrijven, personen, handelingen of gebieden.

10 Sanctiekans De door de doelgroep ingeschatte kans op een sanctie indien na controle een overtreding is geconstateerd.

11 Sanctie-ernst De hoogte en soort van de aan de overtreding gekoppelde sanctie en bijkomende nadelen van sanctieoplegging.

In de praktijk zullen deze elf dimensies samen het nalevingsgedrag van producenten beïnvloeden. Per wetgevingsgebied en doelgroep is er echter een beperkt aantal dimensies dat grotendeels het nalevingsgedrag bepaalt: $80 \%$ van het nalevingsgedrag wordt bepaald door $20 \%$ van de dimensies, de zogenoemde kerndimensies. Effectieve gedragsverandering vereist vaak een beïnvloeding van alle kerndimensies (CCV 2010). Om inzicht te krijgen in welke interventiemaatregelen het effectiefst zijn om 
naleving te bevorderen, zouden deze dimensies tegelijkertijd bestudeerd moeten worden.

Bij het RIKILT wordt daarom onderzoek gedaan naar het ontwikkelen van een algemeen toepasbaar model voor simulatie van nalevingsgedrag, waarin deze dimensies verwerkt zijn. Hierbij wordt gebruikgemaakt van Agent Based Modeling.

\section{Agent Based Modeling}

Agent Based Modeling (ABM) is een methode die de laatste jaren steeds meer in de belangstelling staat. Op zichzelf is ABM niet nieuw; in sommige toepassingsdomeinen (bijvoorbeeld de biologie) staat deze methode al jaren bekend als Individual Based Modeling (Judson, 1994). Kern van de methode is het modelleren van individuen (agents) met attributen en gedragsregels. Een agent kan van alles zijn: een mens, een dier, een bedrijf, een cel, enzovoort. Een voorbeeld van een attribuut is 'leeftijd', of 'grade' (deze laatste wordt later in dit artikel uitgelegd). Omdat de waarden voor attributen van agents onderling van elkaar kunnen verschillen, kan ook het gedrag verschillen. Zo zal bijvoorbeeld bepaald gedrag pas geprikkeld worden als een attribuut of een combinatie van attributen boven een drempelwaarde uitkomt, zodat de ene agent het gedrag wel zal vertonen en de andere niet. Verder kunnen agents onderlinge interactie hebben (zij kunnen boodschappen met elkaar uitwisselen, zoals de waarde van bepaalde attributen). Ook deze interacties gebeuren alleen onder voorgeschreven omstandigheden. Zo kan het bijvoorbeeld zijn dat agents alleen kunnen 'zien' wat hun omringende buren doen, maar niet wat agents doen die zich verder weg bevinden. In veel toepassingen wordt ook de omgeving mee-gemodelleerd: agents kunnen dan beslissingen maken op basis van geografische informatie. Door simulaties te runnen met verschillende beginsituaties kan inzicht verkregen worden in het gedrag van de individuen en het hele systeem. Het is een techniek die in een breed gebied wordt toegepast van biologie tot verkeersproblemen, maar vooral in de economie en sociale wetenschappen (samen 53\% van alle toepassingen) (Heath et al., 2009). Vooralsnog wordt deze techniek nog weinig toegepast op het gebied van voedselveiligheid. Er is ons één toepassing bekend waarbij gekeken werd naar het effect van communicatie en beloningssystemen op het gedrag van melkveehouders in de bestrijding van mastitis. Zowel economische als sociale factoren werden hierin meegenomen (Verwaart \& Valeeva, 2011).

Bij andere methoden wordt soms veel waarde gehecht aan het precies voorspellen van modeluitkomsten. Dat is bij een ABM erg moeilijk, want naast de keuze voor instellingen van parameters (die je bij andere methoden ook hebt) is het gedrag vaak onvoorspelbaar, juist doordat je met agents werkt, die zich individueel gedragen. Doordat er bij de simulaties altijd random effecten meespelen (bijvoorbeeld alleen al in de volgorde waarin agents hun beslissingen mogen nemen, die mogelijk weer van elkaar afhangen), zijn de uitkomsten nooit precies hetzelfde. Door nu voldoende simulatieruns te doen en de gevoeligheid van de parameters systematisch te testen kan toch een uitspraak gedaan worden over de mogelijke gedragingen van het systeem, gegeven de aannames.

In tegenstelling tot andere simulatiemodellen is ABM in staat de heterogeniteit van individuen en de interacties tussen individuen te beschrijven, zodat op sectorniveau patronen en overall gedrag naar voren komen die niet op voorhand expliciet gemodelleerd zijn. Zo kan bepaald gedrag zich soms wel en soms niet voordoen, of wordt door een bepaalde combinatie van parameters ineens een omslagpunt in gedrag bereikt. Dit is heel relevant voor situaties waarin niet alle aannames bekend zijn en waarin willekeurigheid een rol kan spelen (zoals het leven van alledag). Zonder dat we het systeem 'in werkelijkheid' hoeven te runnen, kunnen we toch kijken wat er zou kunnen gaan gebeuren. Een voorbeeld van een ABM met een verrassende conclusie is de beschrijving van groepsgedrag tijdens evacuatie bij een brandalarm. Hieruit bleek dat het plaatsen van een pilaar schuin voor de nooduitgang zorgde voor optimale doorstroming, waardoor na 45 seconden alle mensen ongedeerd de ruimte konden verlaten. Zonder pilaar was in dezelfde tijd slechts $60 \%$ van de mensen geëvacueerd, waarvan $10 \%$ gewond was. Deze simulatie is ook getest in een praktijkruimte en de voorspellingen bleken te kloppen met de werkelijkheid (Helbing et al., 200o).

Sterke punten van ABM zijn dus onder andere het 'ermergent behaviour', het kunnen schakelen tussen niveaus (zowel het individu als de hele sector kunnen bekijken - bijvoorbeeld om te zien wat er met bepaalde individuen gebeurt die zich anders gedragen dan gemiddeld), de sociale component van interacties (of die interactie nu tussen mensen of tussen cellen is) en de transparantie van modelleren (die ook voor niet-ingewijden vaak gemakkelijk te volgen is).

Voor situaties waarbij het gaat om harde voorspellingen, waarbij geen ruimte is voor onzekerheid, is ABM minder geschikt. Maar voor beleidsvraagstukken waarbij sommige aannames überhaupt niet hard te maken zijn, is ABM een interessante methode om inzicht te krijgen in de onderliggende processen en de 'what if'-scenario's die zich kunnen voordoen.

\section{Casestudie: nalevingsgedrag van varkenshouders}

Om te onderzoeken of ABM toepasbaar is voor de simulatie van nalevingsgedrag, is uitgegaan van een casestudie, gericht op het correct gebruik van antibiotica bij varkenshouders. Volgens de diergeneesmiddelenwet en diergeneesmiddelenregeling dienen varkenshouders antibioticagebruik te registreren en deze informatie door te geven aan het slachthuis. Verder dienen ze zich te houden aan de wachttijden van de antibiotica. Dit betekent dat na toediening van antibiotica een bepaalde tijd gewacht dient te worden, voordat het varken afgeleverd mag worden bij het slachthuis. Dit is om te voorkomen dat het vlees antibioticaresiduen bevat die de wettelijke norm overschrijden. Een recente Deense studie liet zien dat soms toch residuen aangetoond werden in het vlees, wat erop wijst dat varkenshouders zich niet altijd aan de wetgeving houden (Alban et al., 2011).

Om nalevingsgedrag te kunnen simuleren is een model ontwikkeld met behulp van Netlogo, een ABM-ontwikkelomgeving (Wilensky, 1999), waarin het gedrag van individuele varkenshouders en hun interacties is beschreven om zo iets te kunnen zeggen over het nalevingsgedrag van de gehele doelgroep. Figuur 1 laat de individuele varkenshouders zien die hierin beschreven zijn. In de figuur is te zien dat varkenshouders zich ofwel aan de wet houden (groen) of niet (rood). Naast de varkenshouders is een getal weergegeven ('grade'); dit geeft het nalevingsgedrag uit het verleden weer, variërend van goed gedrag (5 punten) tot slecht gedrag (1 punt). In het veld lopen inspecteurs rond (blauw), die na het constateren van een overtreding (rode varkenshouders) een punt aftrekken van de grade van de varkenshouder en een punt optellen als er sprake is van goed gedrag (groene varkenshouders). In het model is aangenomen dat wanneer de varkenshouder op o komt (dus na herhaalde boetes), deze zijn/haar bedrijf tijdelijk (gedurende zes maanden) moet sluiten en dus geen varkens mag leveren aan het slachthuis. 


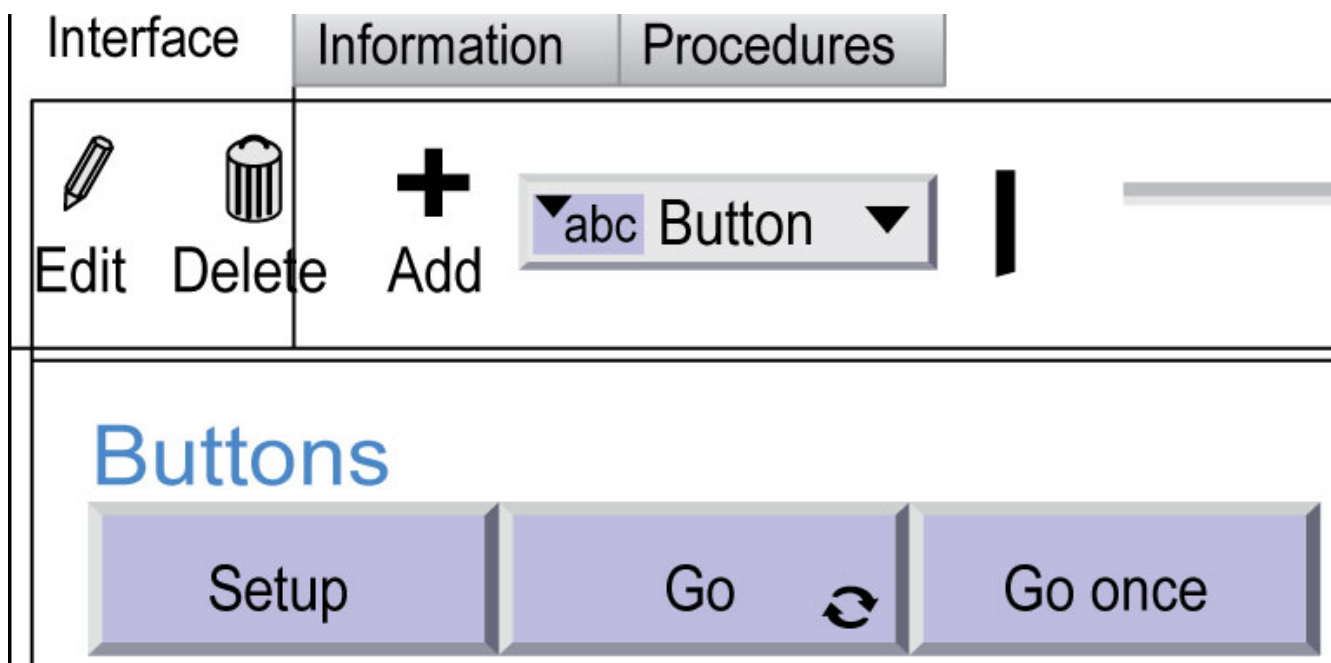

\section{Switches}

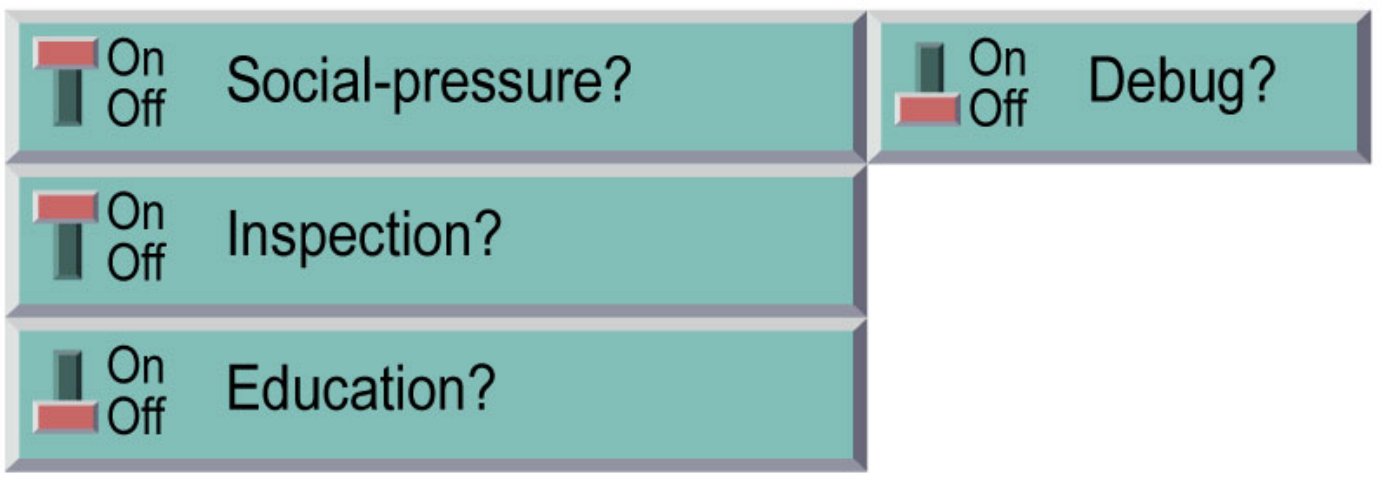

\section{Settings}

\begin{tabular}{|c|c|c|c|}
\hline Number-of-farmers & 500 & Acceptation & 0.70 \\
\hline Scope-social-influence & 3 & Imitation-probability & 0.50 \\
\hline Inspectors & 5 & Risk-based-inspection & 1.00 \\
\hline Detection-probability & 0.40 & Closure-term-business & 6 \\
\hline Educators & 3 & Education-probability & 10 \\
\hline
\end{tabular}


Inconsiously-non-compliant $\quad 0.030$

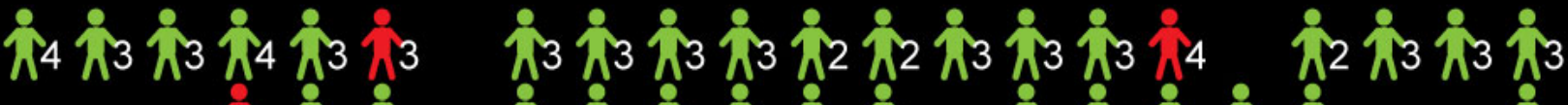

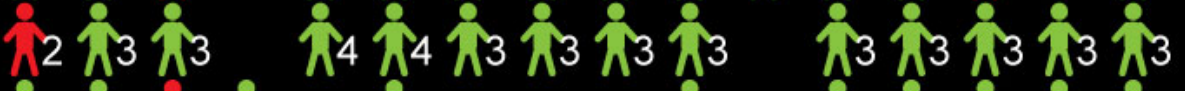

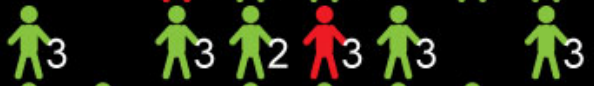

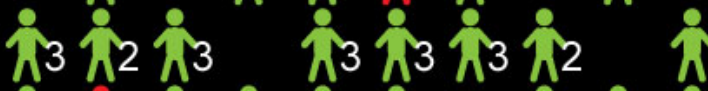

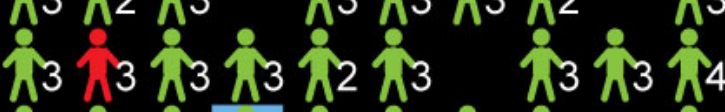

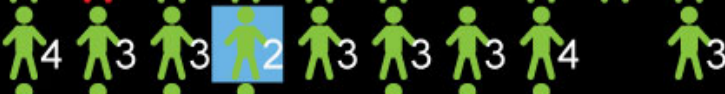

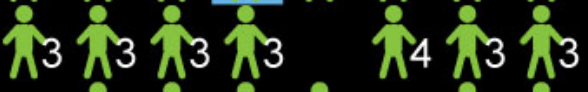

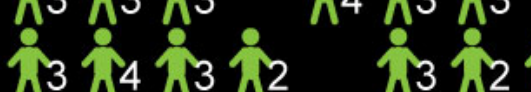

2

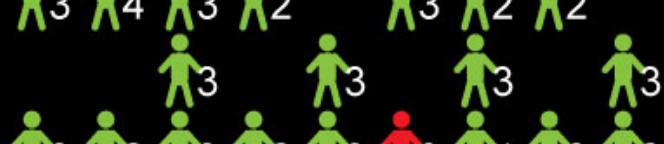

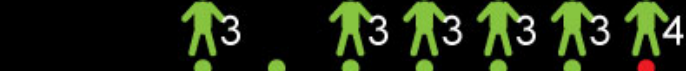

- $\pi^{3} \pi^{3}$

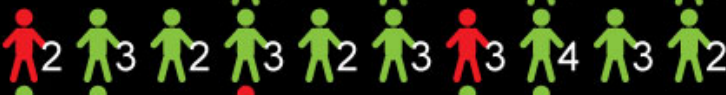

皮年

然

$\sqrt{3}$

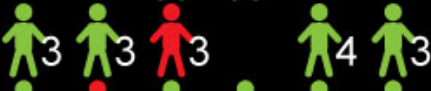

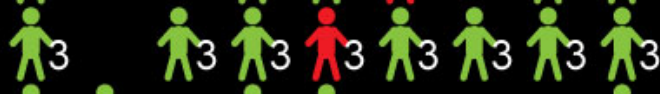

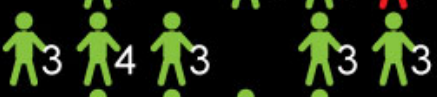

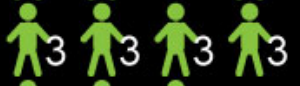

s

公 4 / 3

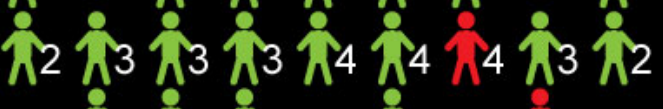

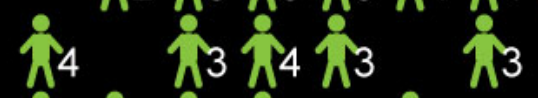

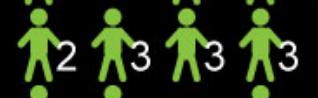

, 3

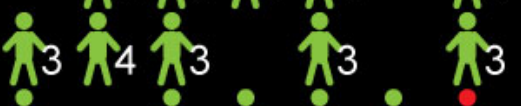

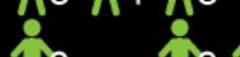

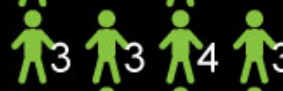

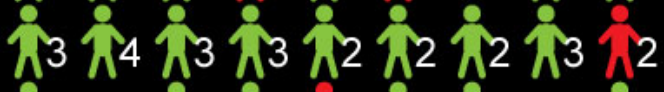
皮余布 少

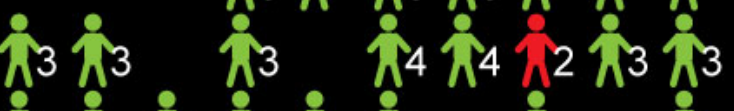

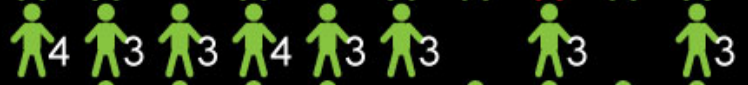
更交 象

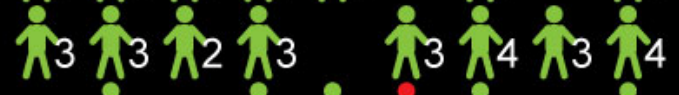

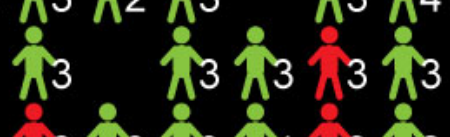

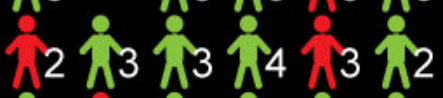
急

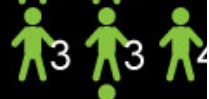
$\sqrt{2}$

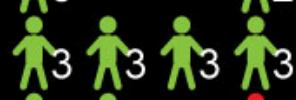

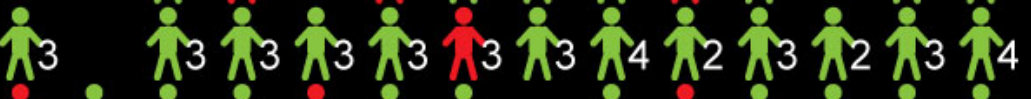

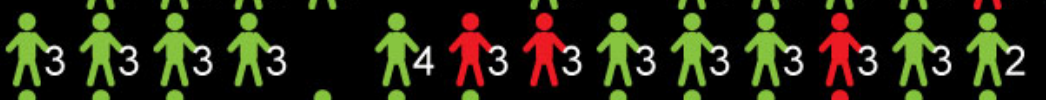

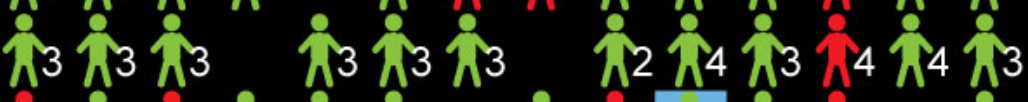

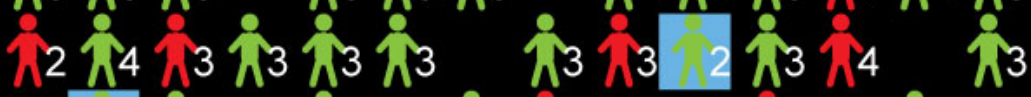
$2 \pi^{4} \frac{\pi^{3}}{\pi_{3}} \pi_{3}$

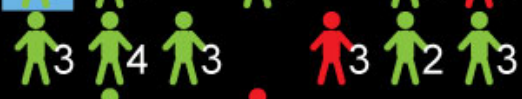
皮公

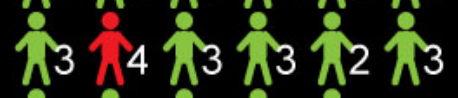

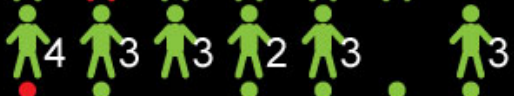

\section{Sis}

13 尔 象众

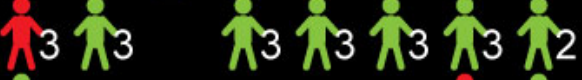
交公4

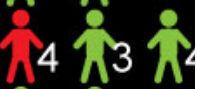
象 象

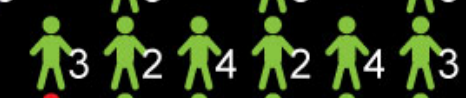

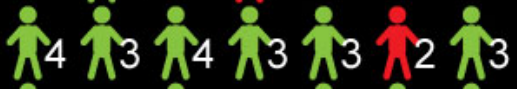

$13 \%$

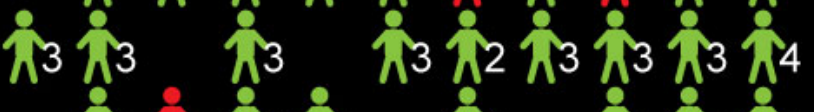

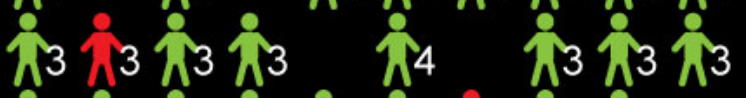

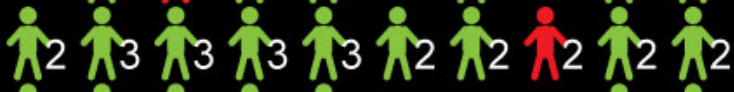

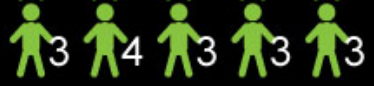
皮皮

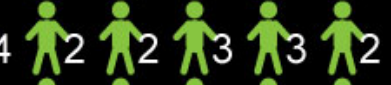

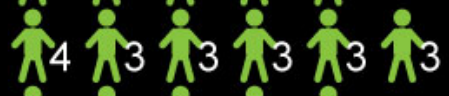

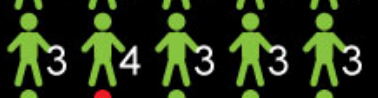

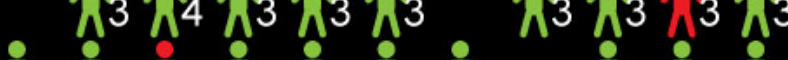

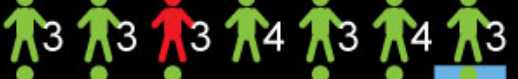

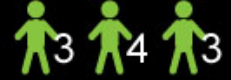

初

1 Interface van het Agent Based Model voor naleving van antibioticagebruik bij varkenshouders. Links zijn de knoppen en sliders weergegeven die gebruikt kunnen worden om variaties aan te brengen in diverse dimensies van de T11. Rechts is een overzicht te zien van nalevende varkenshouders (groen), niet-nalevende varkenshouders (rood) en inspecteurs (blauw). Cijfers naast de varkenshouders geven historisch inspectiegedrag weer, waarbij 5 de hoogste en 1 de laagste mate van naleving is.

Allereerst is aan de hand van literatuur en expertkennis onderzocht wat de belangrijkste T11-dimensies waren voor deze casestudie. Uit Europese studies bleek dat de algehele naleving over het algemeen hoog is, terwijl de handhavingsdimensies (T6T11) als laag worden ingeschat (May, 2005; Dernburg et al., 2007; Jongeneel et al., 2007). Acceptatie van de wetgeving (T3) blijkt hierbij een belangrijke rol te spelen. Door grotere bewustwording bij varkenshouders over de gevolgen van antibioticagebruik zijn 
deze eerder geneigd de wet rondom antibioticagebruik na te leven. Naast acceptatie spelen kosten-baten overwegingen (tijd, geld, moeite en reputatie) (T2) ook een belangrijke rol bij de naleving. De belangrijkste sociale dimensies in deze casestudie zijn dan ook de kosten-batenoverwegingen (T2) en de mate van acceptatie (T3). In deze studie is vooral gekeken naar dit laatste aspect. Om te onderzoeken of naleving verhoogd kan worden door wijziging in handhaving is het effect van kans op inspectie (T7) op nalevingsgedrag onderzocht. Verder bleek uit een Deense studie dat de overtuiging dat andere varkenshouders de wet naleven een belangrijke motivatie was voor de eigen naleving (May, 2005). Alhoewel deze factor niet expliciet in de T11 is opgenomen, is dit wel meegenomen in de huidige studie.

De verschillende factoren zijn als volgt ingebouwd in het ABM. De mate van acceptatie ( $\left.\mathrm{T}_{3}\right)$ is ingebouwd door de varkenshouders te verdelen in accepterende en niet-accepterende varkenshouders, die bij de start van de simulatie een verschillende status krijgen. Deze mate van acceptatie is een parameter in het model, die gevarieerd kan worden. Dit komt overeen met de werkelijkheid, waarin de mate van acceptatie tussen groepen varkenshouders ook varieert (May, 2005; Dernburg et al., 2007). Aangenomen is dat het nalevingsgedrag van niet-accepterende varkenshouders bepaald wordt door de ingeschatte inspectiekans, de kans dat ze tijdelijk moeten sluiten, hun eigen risicovermijdend gedrag en het belang dat ze hechten aan hun reputatie (T2). De kans op inspecties $\left(\mathrm{T}_{7}\right)$ is ingebouwd door een slider in te voegen waarmee het aantal inspecteurs gewijzigd kan worden. Hoe meer inspecteurs, hoe hoger de kans op inspectie. In het model is aangenomen dat een niet-accepterende varkenshouder zijn gedrag verbetert wanneer er per maand één of meer inspecties per 100 varkenshouders worden uitgevoerd. Dit aantal is onder andere gebaseerd op de inspectiefrequenties zoals voorheen uitgevoerd door de Algemene Inspectiedienst (VWA, 2007). Verder is sociale beïnvloeding ingebouwd door varkenshouders het gedrag van hun directe omgeving te laten kopiëren. De mate waarin dat gebeurt, is ook een model-parameter. Wanneer alle varkenshouders in de directe omgeving van een specifieke varkenshouder 'rood' zijn, is de kans dat deze specifieke varkenshouder ook 'rood' wordt, aanzienlijk hoger dan wanneer dit niet het geval is.

\section{Simulaties}

Door middel van simulaties met het zojuist beschreven model is onderzocht wat het effect is van de mate van acceptatie, het aantal inspecteurs en sociale beïnvloeding op de naleving van antibioticawetgeving rondom wachttijden (figuur 2 en 3 ).

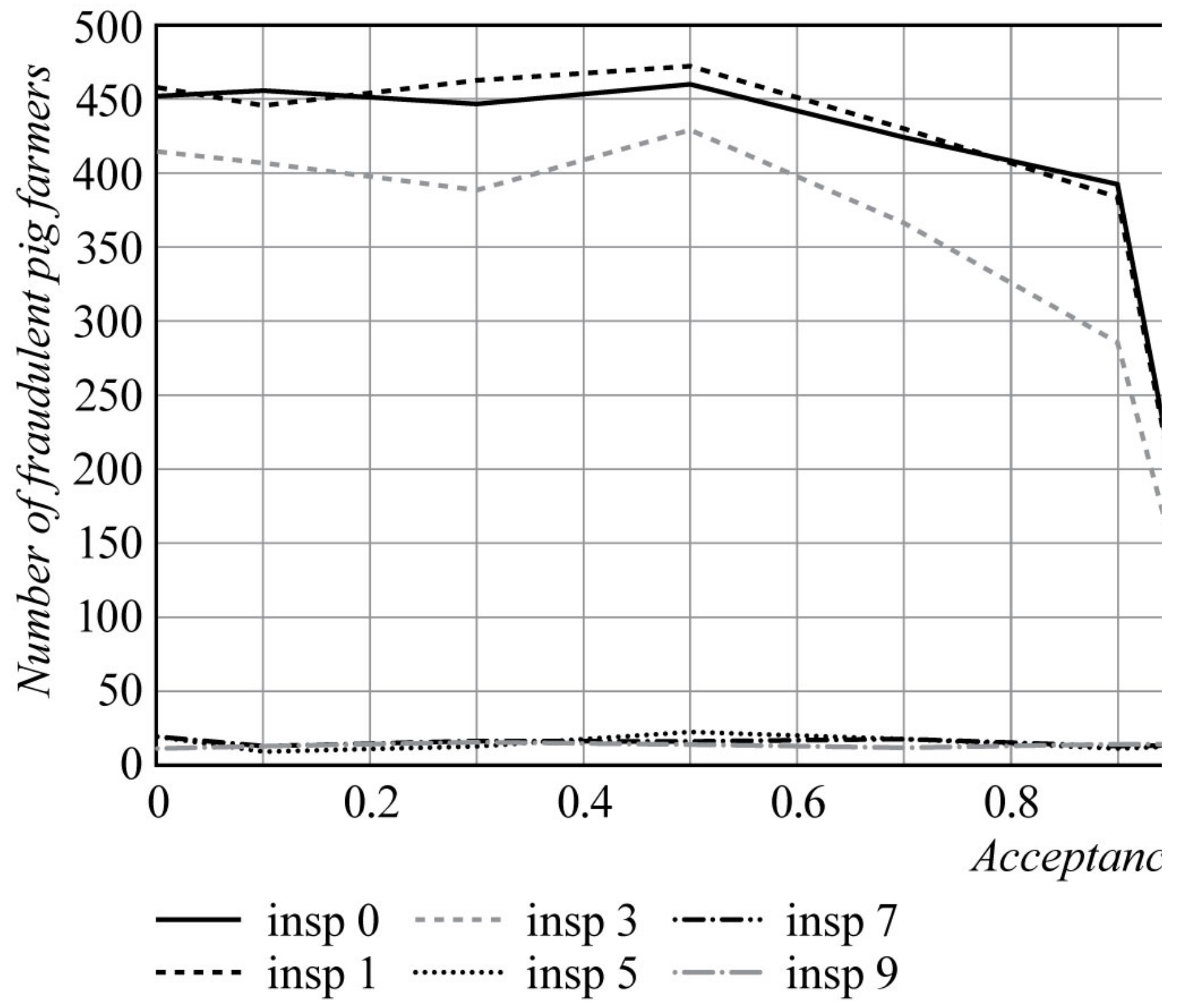

2 Effect van de mate van acceptatie en het aantal inspecteurs op het aantal frauderende varkenshouders na 15 jaar 

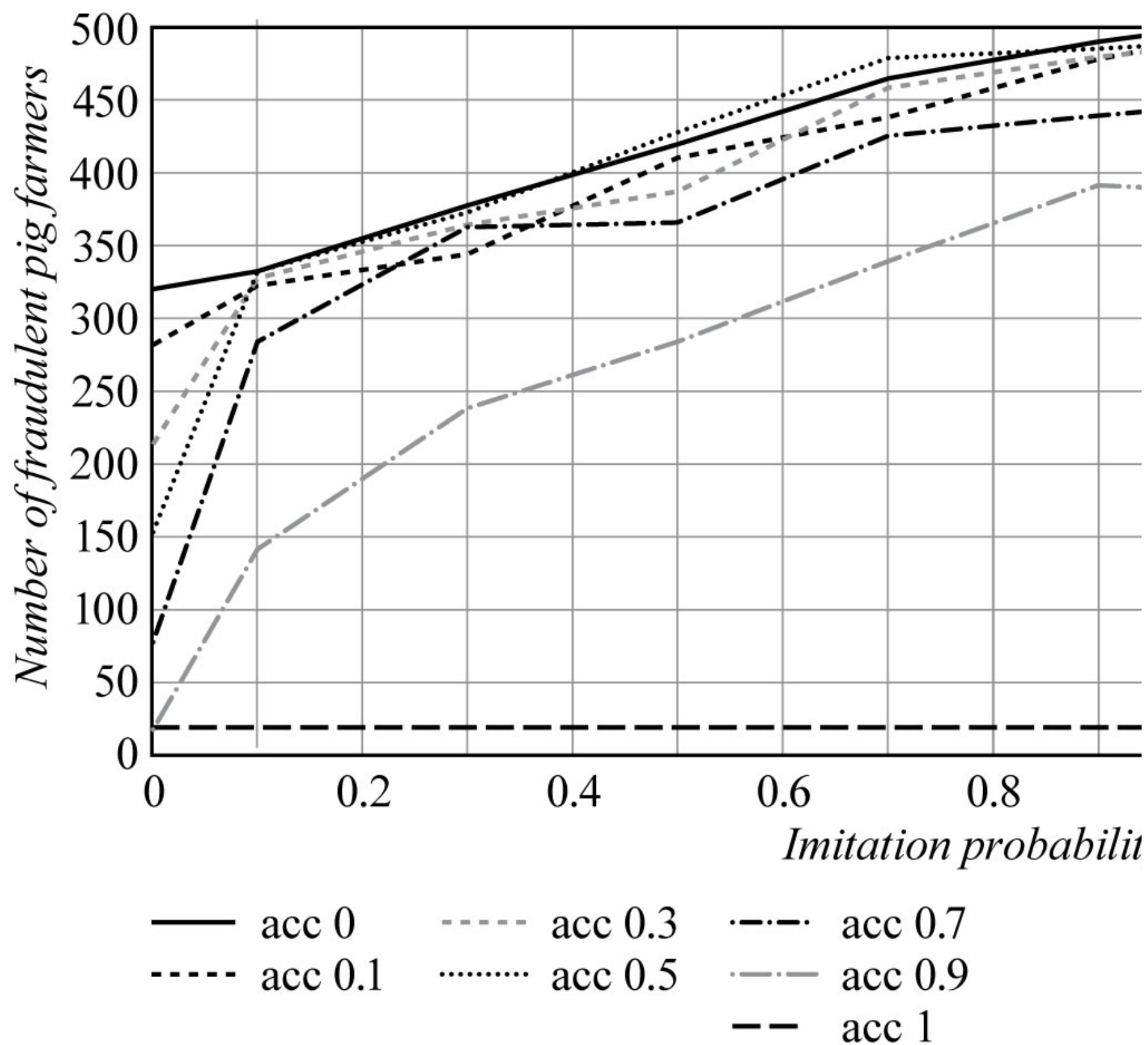

3 Effect van imitatiekans en mate van acceptatie op het aantal frauderende varkenshouders na 15jaar

Figuur 2 laat zien dat als het aantal inspecteurs groter is dan 5 (dus meer dan 1 inspectie per 100 varkenshouder per maand), het aantal frauderende varkenshouders aanzienlijk daalt. Het lijkt inderdaad aannemelijk dat er een punt is, waarop een varkenshouder de inspectiekans hoger inschat dan het risico dat hij bereid is te nemen en hij dus zal besluiten tot naleving. Dit punt zal echter per varkenshouder verschillend zijn en zal dus niet voor iedereen rond de ingestelde o,01 liggen. Bij ABM gaat het echter niet om een exacte voorspelling van een situatie te geven, maar om de trends inzichtelijk te maken en te begrijpen. Zo laat de figuur zien dat een verdere toename in het aantal inspecteurs boven dit keerpunt niet zal leiden tot een verdere daling in het aantal frauderende varkenshouders. Meer inspecties betekent dus niet per definitie betere naleving. Verder laten figuur 2 en 3 zien dat als de inspectiekans laag is ( $<5$ inspecteurs), de mate van acceptatie een belangrijke rol speelt bij de naleving. Een hoge mate van acceptatie ( $>70 \%$ ) geeft een duidelijke daling in het aantal frauderende varkenshouders. Dit komt overeen met resultaten uit Denemarken en Frankrijk, waarin de inspectiekans laag wordt ingeschat, maar dankzij de hoge mate van acceptatie een hoog nalevingspercentage wordt behaald (May, 2005; Dernburg et al., 2007). Figuur 3 laat verder zien dat wanneer de imitatiekans toeneemt (dus meer varkenshouders nemen het gedrag van hun omgeving over), het aantal frauderende varkenshouders ook toeneemt. Dit komt omdat de accepterende varkenshouders het gedrag van niet-accepterende varkenshouders meer kopiëren dan andersom. In het model is aangenomen dat niet-accepterende varkenshouders verschillende aspecten in overweging nemen voor het wel/niet naleven (zoals de inspectiekans en het belang van hun reputatie). Deze varkenshouders worden dan ook minder (positief) beïnvloed door hun omgeving dan de accepterende varkenshouders die in feite wel bereid zijn na te leven, maar bij verminderde inspectiekans uiteindelijk toch het gedrag van andere niet-nalevende varkenshouders gaan overnemen. De simulaties laten zien dat wanneer de mate van acceptatie hoog is, er toch altijd een zekere mate van inspectie nodig zal blijven om het nalevingsniveau hoog te houden.

\section{Discussie}

Het ontwikkelde model is geschikt om 'what if'-scenario's mee uit te voeren. Hierbij is het belangrijk te bedenken dat de resultaten van het model gezien moeten worden in relatie tot de aannames die zijn gedaan in het onderliggende model. Die aannames zitten 
in de gebruikte mechanismen (door welke zaken laten varkenshouders zich beïnvloeden?) en de hoogte van wegingsfactoren daarbij (hoe sterk weegt de beïnvloeding van elk van die zaken mee?). Sommige daarvan zijn parameters die tijdens modelruns gevarieerd kunnen worden, maar andere zijn inherent aan het gekozen model. Er hadden ook andere mechanismen en parameterwaarden gebruikt kunnen worden, waarmee de resultaten er mogelijk anders uit zouden zien. Om vertrouwen in het model te krijgen is dus validatie nodig, wat in het geval van ABM's nog niet zo gemakkelijk is, omdat empirische gegevens over bijvoorbeeld beïnvloedingsmechanismen zeer moeilijk te verkrijgen zijn. In zulke gevallen wordt vaak expertvalidatie toegepast: er moeten kwalitatieve overeenkomsten zijn tussen model en werkelijkheid, die herkenbaar moeten zijn voor experts. In dit geval is het model voorgelegd aan experts van de NVWA, die voldoende overtuigd waren van de aannemelijkheid van het getoonde gedrag. Verdere validatie kan worden verkregen door het effect van bepaalde interventies te vergelijken met gegevens uit de praktijk. Zo kan bijvoorbeeld het effect van hogere boetes op nalevingsgedrag gesimuleerd worden met behulp van ABM. Het aantal boetes dat voor en na de verhoging is uitgeschreven, kan dan vergeleken worden met de ABM voorspellingen. Naast validatie van de output is het ook belangrijk de input zo veel mogelijk te onderbouwen. In het huidige model zijn parameters zoals de inspectiekans gebaseerd op literatuur en expertkennis. Hierbij is aangenomen dat er een keerpunt is voor varkenshouders (in dit geval een inspectiekans van 1\%) waarboven de varkenshouder zal naleven. Dit kan realistischer worden ingebouwd door hier gradaties in mee te nemen, aangezien niet elke varkenshouder bij dezelfde inspectiekans zijn gedrag zal aanpassen. De mate van acceptatie is ingebouwd als een slider en kan dus in de simulaties aangepast worden. Het effect van sociale beïnvloeding is ook ingebouwd met behulp van een slider (imitatiekans), waarbij aangenomen is dat als gedrag gekopieerd wordt, de varkenshouder het gedrag $100 \%$ kopieert. In de praktijk zal een varkenshouder niet zo abrupt zijn gedrag veranderen. Dit is dus een aspect dat nader uitgezocht moet worden, waarbij gebruikgemaakt zou kunnen worden van kansverdelingen.

\section{Conclusies en vervolgonderzoek}

Alhoewel ABM niet in staat is exacte voorspellingen te doen, laten de simulaties in de beschreven casestudie wel zien dat het een interessant model is om verschillende aspecten mee te nemen om zo overall iets te kunnen zeggen over de vraag welke dimensies van belang zijn bij nalevingsgedrag. De beschreven simulaties lieten zien dat een hoge mate van naleving verkregen kan worden door een hoge mate van acceptatie (middels kennisoverdracht of betrokkenheid bij het instellen van wetgeving), maar dat daarbij wel nog altijd een minimumaantal inspecteurs nodig is om dit hoge niveau te handhaven. Verder bleek uit het model dat het gedrag van andere varkenshouders een belangrijke rol speelt bij het individuele gedrag van een varkenshouder.

Het huidige beschreven model is de eerste toepassing van ABM op het gebied van naleving en toezicht, waarbij meerdere factoren uit de T11 zijn meegenomen. Hoewel het huidige model op sommige punten verbeterd kan worden, laat deze toepassing wel duidelijk zien wat het effect is van diverse elementen van de T11 op nalevingsgedrag. Het grote voordeel van ABM is dat verschillende dimensies tegelijkertijd onderzocht kunnen worden. Zo zijn in de hier beschreven casestudie de acceptatie, sociale beinvloeding en de inspectiekans gevarieerd en de effecten hiervan gesimuleerd. Gegeven de aannames stelt het model beleidsmakers en private organisaties in staat op eenvoudige wijze de effecten van verschillende nalevingsstrategieën te beoordelen en een onderbouwde keuze te maken. Zo kunnen alternatieve maatregelen onderzocht worden ingeval verminderd budget leidt tot minder toezicht.

Hoewel het model in eerste instantie is getest op voornoemde case, kan hij, gevoed met informatie uit andere sectoren, voor verschillende segmenten in de levensmiddelensector ingezet worden. Hiertoe zal het ontwikkelde model verder uitgebouwd worden door de koppeling met economische modellen, waarbij bedragen gekoppeld worden aan de opbrengst van de varkens en eventuele kosten van een boete bij wetsovertreding. Dit zal een realistischer beeld geven van de kosten-batenafweging die varkenshouders maken, wat het model zal verbeteren. Verder zal het model getoetst worden aan de hand van andere casestudies en, indien mogelijk, gevalideerd worden aan de hand van praktijkgegevens.

Referenties

Ajzen, I., \& Fishbein, M. (2010). Predicting and changing behavior: The reasoned action approach. New York: Psychology Press.

Alban, L., Baptista, F.M., Olsen, A.-M., \& Petersen, J.V. (2011). Human health risk of residues in Danish pork - in theory and practice (pp. 360-363). Safepork, Maastricht, the Netherlands.

CCV. ( 2010). De tafel van elf - Een veelzijdig instrument. http://www.hetccv.nl/publicaties/webwinkel/Algemeen/tafel-van-elf.

Dernburg, A.R., Fabre, J., Philippe, S., Sulpice, P., \& Calavas, D. (2007). A study of the knowledge, attitudes, and behaviors of French dairy farmers toward the farm register. Journal of Dairy Science, 90, 1767-1774.

Heath, B., Hill, R., \& Ciarallo, F. (2009). A survey of agent-based modeling practices (January 1998 to July 2008). Journal of Artificial Societies and Social Simulation, 12(4), 9.

Helbing, D., Farkas, I., \& Vicsek, T. (2000). Simulating dynamical features of escape panic. Nature, 407, 487-490.

Herzfeld, T., \& Jongeneel, R. (2012). Why do farmers behave as they do? Understanding compliance with rural, agricultural, and food attribute standards. Land Use Policy, 29(1), 250-260.

Jongeneel, R., Brouwer, F., Farmer, M., Müssner, R., De Roest, K., Poux, X., Fox, G., Meister, A., Karaczun, Z., Winsten, J., \& Ortéga, C. (2007). Compliance with mandatory standards in agriculture. A comparitive approach of the EU vis-à-vis the United States, Canada and New Zealand. The Hague: LEI. Report nr. 6.07.21.

Judson, O.P. (1994). The rise of the individual-based model in ecology. Trends in Ecology \& Evolution, 9(1), 9-14.

May, P.J. (2005). Regulation and compliance motivations. Examining different approaches. Public Administration Review, 65 , 31-44. 
Van Asselt, E.D., Sterrenburg, P., Noordam, M.Y., \& Van der Fels-Klerx, H.J. (2012). Overview of available methods for Risk Based Control within the European Union. Trends in Food Science \& Technology, 23(1), 51-58.

Verwaart, T. \& Valeeva, N.I. (2011). An agent-based model of food safety practices adoption. In S. Osinga, G.J. Hofstede \& T. Verwaart (Eds.), Emergent Results of Artificial Economics (pp. 103-114). Berlin/Heidelberg: Springer Verlag.

Wilensky, U. (1999). Netlogo. http://ccl.northwestern.edu/netlogo/.

(C) Boom Lemma uitgevers 